\title{
Enzyme Complex Added to Broiler Diets: Effects on Performance, Metabolizable Energy Content, and Nitrogen and Phosphorus Balance ${ }^{1}$
}

\section{-Author(s)}

\section{Pessôa GBS"}

Ribeiro Junior V"

Albino LFT"

Araújo WAG"I

Silva DL"

Hannas MI"

Rostagno HS"

Project financed by Alltech Agroindustrial Ltda.

" Federal University of Viçosa, Department of Animal Science, Av PH Rolfs S/N, Viçosa 36570-000, MG, Brazil

III Federal Institute of Education, Science and Technology of Northern Minas Gerais, 39480-000, Brazil

\section{Mail Address}

Corresponding author e-mail address Valdir Ribeiro Junior

Rua Pedro Gomide Filho, 95, apto 101

36570-000. Viçosa, MG, Brazil

Tel: (31) 38992261

Email: vrj_zoo@hotmail.com

\section{- Keywords}

Additives, broiler, enzyme.

\section{ABSTRACT}

Two trials were performed to evaluate the effects of an enzyme complex (EC) on broiler performance, metabolizable energy, and phosphorus and nitrogen balance. In the first trial, 960 one-day-old male Cobb broilers were randomly distributed in a $3 \times 2$ factorial arrangement (three nutritional levels and the inclusion or not of EC), totaling six treatments with eight replicates of 20 birds per pen, and reared until 42 days of age. The control diet was formulated to meet the broilers' nutritional requirements. The other diets contained reduced available phosphorus (P), metabolizable energy, and amino acid levels, considering $100 \%$ and $150 \%$ of the EC nutritional matrix. The inclusion of the EC (200 g/ton) resulted in better broiler performance, improving weight gain in $4 \%$ and feed conversion ratio in $3 \%(p<0.05)$. In the second trial, 240 male broilers were randomly distributed into the same treatments with eight replicates of five birds per cage. The method of total excreta collection was used. There was an interaction $(p<0.05)$ between diets and $\mathrm{EC}$ for $\mathrm{P}$ intake, nitrogen $(\mathrm{N})$ intake, and $\mathrm{N}$ retention. The EC supplementation improved nitrogen-corrected apparent metabolizable energy values in $2.02 \%(p<0.05)$. Significant effects were observed on phosphorus and nitrogen balance $(p<0.05)$. Phosphorus retention improved in $10.26 \%$, nitrogen retention increased in $5.3 \%$, while nitrogen excretion decreased in 3.3\%. Based on the results of the present study, we recommend the addition of $200 \mathrm{~g} / \mathrm{t}$ of the enzyme complex to broiler diets, considering nutrient reduction based on $100 \%$ of the EC nutritional matrix.

\section{INTRODUCTION}

Poultry diets are commonly based on corn and soybean meal, and their energy can be fully utilized when exogenous enzymes are added to the feed (Campestrini et al., 2005). Exogenous enzymes improve the nutrient and energy digestibility of feeds commonly offered to broilers (Yang et al., 2010; Hahn-Didde and Purdum, 2014). In general, enzymes breakdown plant cell walls, reduce feed viscosity, and breakdown proteins and antinutritional factors (Cowieson, 2010, Perazzo Costa et al., 2015). However, these benefits depend on the type of enzymes, and each performs a specific function (e.g., phytase, carbohydrases, and proteases).

In order to improve the availability of nutrients and to minimize the adverse effects of antinutritional factors, diets containing either phytase or carbohydrase are commonly used under practical conditions of commercial broiler nutrition (Francesch \& Geraert, 2009; Avila et al., 2012). Previous studies reported improvements in weight gain, feed-togain ratio, and carcass traits of broilers supplemented with exogenous enzyme complexes (García et al., 2008; Boguhn and Rodehutscord, 2010; Farran et al., 2010; Campasino et al., 2015). 
Different strategies for enzyme utilization are applied (decreasing nutrient specifications or assigning nutrient values to the enzymes) when combining two enzyme products (Avila et al., 2012). Commonly, the use of the nutritional matrix of the enzyme products is recommended for feed formulation, allowing the reduction of dietary energy, phosphorus, protein, and amino acid contents (Campasino et al., 2015), which provides benefits such as reducing nutrient environmental excretion and diet costs (DersjantLi et al., 2015). However, studies evaluating the recommendations of reduction of dietary nutrients according to the efficiency of enzyme complexes are needed in order to prevent broiler performance losses.

Thus, this study aimed at evaluating the addition of an enzyme complex on the performance, dietary metabolizable energy content, and nitrogen and phosphorus balance of broilers.

\section{MATERIALS AND METHODS}

Two experiments were conducted at the Experimental Poultry Farm of the Animal Science Department of of the Federal University of Viçosa, state of Minas Gerais, Brazil. Animal care procedures throughout the study complied with the guidelines of the Institutional Animal Care and Use Committee (IACUC) of the UFV (protocol n. 52/2013).

The same starter and grower corn- and soybean meal-based basal diets (Tables 1 and 2) were fed in both trials.

The enzyme complex (EC) consisted of the commercial product ALLZYME SSF (Alltech Agroindustrial Ltda., PR, Brazil), which contains phytase, protease, $x y-$ lanase, ß-glucanase, cellulase, amylase, and pectinase.

The experimental treatments (diets) applied in both trials were: positive control (PC); PC $+200 \mathrm{~g}$ of Enzyme Complex (EC)/t of feed; negative Control 1 (NC1, $100 \%$ of the EC nutritional matrix); $\mathrm{NC} 1+200 \mathrm{~g}$ of EC/t of feed; negative control 2 (NC2, $150 \%$ of the EC nutritional matrix); NC $2+200 \mathrm{~g}$ of EC/t of feed.

The positive control diet (PC) was formulated according to Rostagno et al. (2005) to meet the nutritional requirements of the broilers. The EC was added "on top" (200g/t of feed) in the experimental diets. Based on the positive control diet (PC), the available phosphorus, metabolizable energy and amino acid levels of negative control diets 1 (NC1) and 2 (NC2) were reduced, considering the nutritional matrix of the enzyme complex. Considering $100 \%$ of the nutritional matrix of the enzyme complex, the NC1 diet was formulated reducing available phosphorus level in $0.10 \%$, metabolizable energy content in $75.05 \mathrm{kcal} / \mathrm{kg}$, and digestible amino acid content in $2 \%$ relative to the PC diet. Considering $150 \%$ of the nutritional matrix of the enzyme complex, the NC2 diet was formulated reducing available phosphorus level in $0.15 \%$, metabolizable energy content in $112.6 \mathrm{kcal} /$ $\mathrm{kg}$, and digestible amino acid content in 3\% relative to the PC diet.

Table 1 - Ingredients and nutritional composition (\%) of the experimental diets to broilers from 1 to 21 days of age.

\begin{tabular}{|c|c|c|c|}
\hline Feedstuffs & $\begin{array}{c}\text { Positive } \\
\text { Control (PC) }\end{array}$ & $\begin{array}{c}\text { Negative } \\
\text { Control } 1 \\
\text { (NC1) }\end{array}$ & $\begin{array}{c}\text { Negative } \\
\text { Control } 2 \\
\text { (NC2) }\end{array}$ \\
\hline Corn & 54.895 & 58.596 & 60.391 \\
\hline Soybean meal (46\%) & 38.000 & 36.400 & 35.609 \\
\hline Soybean oil & 3.000 & 1.140 & 0.231 \\
\hline Dicalcium phosphate & 1.830 & 1.283 & 1.014 \\
\hline Limestone & 0.900 & 1.210 & 1.385 \\
\hline Salt & 0.490 & 0.490 & 0.490 \\
\hline DL-Methionine, 99\% & 0.240 & 0.226 & 0.219 \\
\hline L-Lysine $\mathrm{HCl}, 79 \%$ & 0.100 & 0.110 & 0.115 \\
\hline L-Threonine, 98\% & 0.010 & 0.010 & 0.009 \\
\hline Choline chloride (60\%) & 0.100 & 0.100 & 0.100 \\
\hline${ }^{1}$ Vitamin Supplement & 0.120 & 0.120 & 0.120 \\
\hline${ }^{2}$ Mineral Supplement & 0.050 & 0.050 & 0.050 \\
\hline $\begin{array}{l}\text { Anticoccidial agent } \\
\text { (salinomicyn 12\%) }\end{array}$ & 0.055 & 0.055 & 0.055 \\
\hline${ }^{3} \mathrm{BHT}$ & 0.010 & 0.010 & 0.010 \\
\hline Starch & 0.200 & 0.200 & 0.200 \\
\hline \multicolumn{4}{|l|}{ Calculated Values } \\
\hline Crude Protein (\%) & 21.984 & 21.565 & 21.355 \\
\hline $\begin{array}{l}\text { Metabolizable Energy (kcal/ } \\
\mathrm{kg} \text { ) }\end{array}$ & 3000.0 & 2925.0 & 2888.0 \\
\hline Calcium, \% & 0.902 & 0.884 & 0.884 \\
\hline Available Phosphorus, \% & 0.451 & 0.350 & 0.300 \\
\hline $\mathrm{Na}, \%$ & 0.213 & 0.213 & 0.214 \\
\hline$K, \%$ & 0.849 & 0.830 & 0.821 \\
\hline $\mathrm{Cl}, \%$ & 0.377 & 0.380 & 0.382 \\
\hline Total Lysine, \% & 1.263 & 1.236 & 1.222 \\
\hline Digestible Lysine, \% & 1.163 & 1.137 & 1.125 \\
\hline Digestible Methionine, \% & 0.544 & 0.527 & 0.519 \\
\hline Digestible Met + Cys, \% & 0.839 & 0.819 & 0.810 \\
\hline Digestible Threonine, \% & 0.755 & 0.739 & 0.731 \\
\hline Digestible Tryptophan, \% & 0.246 & 0.239 & 0.236 \\
\hline Digestible Arginine, \% & 1.414 & 1.376 & 1.357 \\
\hline Digestible Valine, \% & 0.925 & 0.908 & 0.899 \\
\hline Total Glycine + Valine, \% & 2.000 & 1.960 & 1.940 \\
\hline
\end{tabular}

${ }^{1}$ Vitamin supplement containing (per kg of product): Vit. A - 10,000,000 IU; Vit. D3 2,000,000 IU;Vit. E - 30,000 IU; Vit. B1 - 2.0 g;Vit. B2 - 6.0 g;Vit. B6 - 4.0 g; Vit. B12 $-0.015 \mathrm{~g}$; Pantothenic acid $-12.0 \mathrm{~g}$; Biotin $-0.1 \mathrm{~g}$; Vit. K3 $-3.0 \mathrm{~g}$; Folic acid $-1.0 \mathrm{~g}$; Nicotinic acid - $50.0 \mathrm{~g}$; Selenium - $250.0 \mathrm{mg}$; Excipient - $1000 \mathrm{~g}$; Mineral supplement containing (per kg of product) Iron - $100.0 \mathrm{~g}$; Cobalt - $2.0 \mathrm{~g}$; Copper - $20.0 \mathrm{~g}$; Manganese - $160.0 \mathrm{~g}$; Zinc - $100.0 \mathrm{~g}$; lodine $-2.0 \mathrm{~g}$; Excipient $-500 \mathrm{~g}$;

${ }^{3}$ Butylhydroxytoluene $99 \%$. 
Table 2 - Ingredients and nutritional composition (\%) of the experimental diets to broilers from 21 to 42 days of age.

\begin{tabular}{|c|c|c|c|}
\hline Feedstuffs & $\begin{array}{l}\text { Positive } \\
\text { Control } \\
\text { (PC) }\end{array}$ & $\begin{array}{c}\text { Negative } \\
\text { Control } 1 \\
\text { (NC1) }\end{array}$ & $\begin{array}{c}\text { Negative } \\
\text { Control } 2 \\
\text { (NC2) }\end{array}$ \\
\hline Corn & 60.287 & 63.746 & 65.411 \\
\hline Soybean meal (46\%) & 31.570 & 30.098 & 29.330 \\
\hline Soybean oil & 4.250 & 2.260 & 1.553 \\
\hline Dicalcium phosphate & 1.650 & 1.113 & 0.843 \\
\hline Limestone & 0.850 & 1.198 & 1.374 \\
\hline Salt & 0.470 & 0.469 & 0.469 \\
\hline DL-Methionine, 99\% & 0.240 & 0.214 & 0.209 \\
\hline L-Lysine $\mathrm{HCl}, 79 \%$ & 0.100 & 0.163 & 0.171 \\
\hline L-Threonine, 98\% & 0.010 & 0.025 & 0.026 \\
\hline Choline chloride, (60\%) & 0.100 & 0.100 & 0.100 \\
\hline${ }^{1}$ Vitamin Supplement & 0.100 & 0.100 & 0.100 \\
\hline${ }^{2}$ Mineral Supplement & 0.050 & 0.050 & 0.050 \\
\hline Anticoccidial agent & 0.055 & 0.055 & 0.055 \\
\hline${ }^{3} \mathrm{BHT}$ & 0.010 & 0.010 & 0.010 \\
\hline Starch & 0.200 & 0.200 & 0.200 \\
\hline \multicolumn{4}{|l|}{ Calculated Values } \\
\hline Crude Protein (\%) & 19.415 & 19.033 & 18.820 \\
\hline $\begin{array}{l}\text { Metabolizable Energy } \\
(\mathrm{kcal} / \mathrm{kg})\end{array}$ & 3150.0 & 3075.0 & 3038.0 \\
\hline Calcium, \% & 0.824 & 0.824 & 0.824 \\
\hline Available Phosphorus, \% & 0.410 & 0.311 & 0.261 \\
\hline $\mathrm{Na}, \%$ & 0.205 & 0.205 & 0.205 \\
\hline$K, \%$ & 0.746 & 0.729 & 0.720 \\
\hline $\mathrm{Cl}, \%$ & 0.356 & 0.359 & 0.361 \\
\hline Total Lysine, \% & 1.139 & 1.115 & 1.104 \\
\hline Digestible Lysine, \% & 1.050 & 1.029 & 1.019 \\
\hline $\begin{array}{l}\text { Digestible Methionine, } \\
\%\end{array}$ & 0.505 & 0.487 & 0.480 \\
\hline Digestible Met + Cys, \% & 0.775 & 0.755 & 0.747 \\
\hline Digestible Threonine, \% & 0.684 & 0.669 & 0.663 \\
\hline Digestible Tryptophan, \% & 0.213 & 0.207 & 0.203 \\
\hline Digestible Arginine, \% & 1.227 & 1.193 & 1.174 \\
\hline Digestible Valine, \% & 0.820 & 0.804 & 0.795 \\
\hline Total Glycine + Serine, \% & 1.768 & 1.732 & 1.712 \\
\hline
\end{tabular}

1 Vitamin supplement containing (per kg of product): Vit. A - 10,000,000 l.; Vit. D3 $-2,000,000$ IU; Vit. E - 30,000 IU; Vit. B1 - 2.0 g; Vit. B2 - 6.0 g; Vit. B6 - 4.0 g; Vit. B12 - $0.015 \mathrm{~g}$; Pantothenic acid - $12.0 \mathrm{~g}$; Biotin - $0.1 \mathrm{~g}$; Vit. K3 - $3.0 \mathrm{~g}$; Folic acid - 1.0 g; Nicotinic acid - 50.0 g; Selenium - 250.0 mg; Excipient - 1000 g;

${ }^{2}$ Mineral supplement containing (per $\mathrm{kg}$ of product): Iron - $100.0 \mathrm{~g}$; Cobalt - $2.0 \mathrm{~g}$; Copper - $20.0 \mathrm{~g}$; Manganese - $160.0 \mathrm{~g}$; Zinc - $100.0 \mathrm{~g}$; lodine - $2.0 \mathrm{~g}$; Excipient - $500 \mathrm{~g}$; ${ }^{3}$ Butylhydroxytoluene $99 \%$.

In the first trial, 960 one-d-old male Cobb 500 broiler chicks (average initial weight of $42.5 \mathrm{~g}$ ) were distributed according to a completely randomized design with a 3 $\times 2$ factorial arrangement (three nutritional levels and the inclusion or not of the enzyme complex), totaling six treatments with eight replicates of 20 broilers each. Birds were housed in a conventional masonry broiler house in $1.0 \mathrm{~m} \times 1.5 \mathrm{~m}$ pens equipped with tube feeders and nipple drinkers. Birds were offered water and feed ad libitum during the entire experimental period.

A minimum-maximum thermometer was used to record daily temperature inside the house. From 1 to 21 days, maximum and minimum temperatures were $31.55 \pm 2.99^{\circ} \mathrm{C}$ and $22.84 \pm 2.24{ }^{\circ} \mathrm{C}$, whereas from 21 to 42 days the maximum and minimum temperatures were $29.47 \pm 2.89{ }^{\circ} \mathrm{C}$ and $21.76 \pm$ $1.52{ }^{\circ} \mathrm{C}$, respectively. During the trial, maximum and minimum house temperatures recorded were $30.95 \pm$ $2.32{ }^{\circ} \mathrm{C}$ and $23.5 \pm 2.84^{\circ} \mathrm{C}$, respectively.

Birds were weighed at the beginning of the experiment and at 42 days of age, as well as the feed supplied in order to determine feed intake and weight gain. Subsequently, the feed conversion ratio (FCR) was calculated.

In the second trial, 240 15-day-old male Cobb 500 broiler chicks were distributed according to a completely randomized experimental design into six treatments (identical to first study), with eight replicates of five birds each.

One-d-old chicks were housed in a typical broiler house divided in brooding circles, with the floor covered with wood-shavings litter. Starter feed and water were offered ad libitum. On day 14, birds were individually weighed and distributed in battery cages.

The study was carried out for 10 days, including five days for bird adaptation to the cages, diets, and followed by five days of total excreta collection. Excreta were collected twice daily, at 08:00 and 16:00, from the plastic-lined trays under the cages, placed in duly identified plastic bags, and stored in a freezer until the experiment was completed. At the end of the experimental period, excreta were thawed, weighed, and homogenized for the collection of samples (300 $\mathrm{g})$, which were pre-dried in a forced-ventilation oven at $55^{\circ} \mathrm{C}$ for $72 \mathrm{~h}$.

Excreta samples were analyzed for dry matter, crude protein, gross energy, and phosphorus contents at the Animal Nutrition Laboratory of the Department of Animal Science of UFV.

Nitrogen $(\mathrm{N})$ content in the diets and excreta was determined by the method of Kjeldahl, as described by Silva \& Queiroz (2006). Based on the nitrogen balance and gross energy results of the diets and the excreta determined in a bomb calorimeter (model Parr 1271), apparent metabolizable energy corrected for nitrogen balance (AMEn) was calculated using the equation described by Sakomura \& Rostagno (2007). 
All data collected from both trials were analyzed using the GLM procedure of SAS (SAS Institute, 2010, Version 9.1.3). Data were submitted to analysis of variance (ANOVA) and means were compared by the SNK test at $5 \%$ of probability level.

\section{RESULTS AND DISCUSSION}

In both trials, the average environmental temperature was below the recommended range for the starter period; however, this does not seem to have affected broiler performance.

In the first trial, there was no significant interaction ( $p>0.05$ ) between dietary nutritional levels and enzyme complex (EC) for all performance traits (Table 3).

Table 3 - Performance of broilers fed diets supplemented or not with an enzyme complex from 1 to 42 days of age.

\begin{tabular}{lccc}
\hline Item & $\begin{array}{c}\text { Weight Gain } \\
(\mathrm{kg})\end{array}$ & $\begin{array}{c}\text { Feed Intake } \\
(\mathrm{kg})\end{array}$ & $\begin{array}{c}\mathrm{FCR} \\
(\mathrm{kg} / \mathrm{kg})\end{array}$ \\
\hline Diets & & & \\
Positive Control (PC) & $2.503^{\mathrm{A}}$ & $4.193^{\mathrm{A}}$ & $1.676^{\mathrm{A}}$ \\
Negative Control 1 (NC1) & $2.397^{\mathrm{B}}$ & $4.086^{\mathrm{B}}$ & $1.706^{\mathrm{AB}}$ \\
Negative Control 2 (NC2) & $2.360^{\mathrm{B}}$ & $4.069^{\mathrm{B}}$ & $1.726^{\mathrm{B}}$ \\
Enzyme complex & & & \\
0 & $2.373^{\mathrm{x}}$ & 4.093 & $1.725^{\mathrm{y}}$ \\
200 g/ton & $2.466^{\mathrm{y}}$ & 4.139 & $1.679^{\mathrm{x}}$ \\
$\mathrm{CV}(\%)$ & 2.39 & 2.38 & 2.78 \\
p-Value & & & \\
Diets & $<0.001$ & $<0.001$ & $<0.001$ \\
Enzyme complex & $<0.001$ & $\mathrm{~ns}$ & 0.017 \\
Diets x Enzyme complex & $\mathrm{ns}^{*}$ & $\mathrm{~ns}$ & $\mathrm{~ns}$ \\
\hline
\end{tabular}

${ }^{1} \mathrm{NC} 1=\mathrm{PC}-75.05 \mathrm{kcal} / \mathrm{kg} \mathrm{ME},-0.10 \%$ available $\mathrm{P}$ and $-2.00 \%$ Digestible AA; NC2 = PC $-112.6 \mathrm{kcal} / \mathrm{kg} \mathrm{ME},-0.15 \%$ available P and $-3.00 \%$ Digestible AA.

$A, B$ Means followed by different superscripts in the same column are different by the SNK test $(p<0.05)$.

x.y Means followed by different superscripts in the same column are different by the $F$ test $(p<0.05)$.

*not significant.

The broilers fed the PC diet showed higher weight gain $(5.35 \%)$ and feed intake $(2.83 \%)$ than those fed the NC1 and NC2 diets, respectively $(p<0.05)$. Despite the higher feed intake observed in birds fed PC diet, their feed-to-gain ratio was equivalent to that of birds fed NC1, and better than that ratio observed in the birds fed the NC2 diet, which may be explained by their higher weight gain.

The broilers fed diets supplemented with the EC gained $3.92 \%$ more weight than those fed the diets without EC. These results are consistent with other studies that reported higher weight gain in 42-d-old broilers fed diets with multiple enzyme complexes (Figueiredo et al., 1998; West et al., 2007; García et al., 2008; Farran et al., 2010; Tiwari et al., 2010; Iwahashi et al, 2011).
In the present study, feed intake was not affected by EC ( $p>0.05)$, which is in agreement with the results reported by several authors (Costa, 1996; Figueiredo et al., 1998). However, the birds fed the diets containing EC presented an improvement by $2.67 \%$ in FCR $(p<0.05)$, which indicates that EC dietary supplementation enhanced mainly dietary nutrient absorption efficiency.

Table 4 - Apparent metabolizable energy (AME) and nitrogen-corrected apparent metabolizable energy (AMEn) contents of the diets with the inclusion or not of the enzyme complex.

\begin{tabular}{lcc}
\hline Item & AME $(\mathrm{kcal} / \mathrm{kg})$ & AMEn $(\mathrm{kcal} / \mathrm{kg})$ \\
\hline Diet $^{1}$ & & \\
Positive Control (PC) & $3426.9^{\mathrm{A}}$ & $3334.4^{\mathrm{A}}$ \\
Negative Control 1 (NC1) & $3356.6^{\mathrm{B}}$ & $3266.9^{\mathrm{B}}$ \\
Negative Control 2 (NC2) & $3355.9^{\mathrm{B}}$ & $3261.2^{\mathrm{B}}$ \\
Enzyme complex & & \\
0 & $3345.6^{\mathrm{y}}$ & $3254.5^{\mathrm{y}}$ \\
200 g/ton & $3414.2^{\mathrm{x}}$ & $3320.5^{\mathrm{x}}$ \\
$\mathrm{CV}(\%)$ & 2.60 & 2.54 \\
\hline -Value & & \\
Diets & 0.041 & 0.03 \\
Enzyme complex & 0.009 & 0.009 \\
Diets x Enzyme complex & $\mathrm{ns}$ & $\mathrm{ns}$ \\
\hline
\end{tabular}

${ }^{\prime} \mathrm{NC} 1=\mathrm{PC}-75.05 \mathrm{kcal} / \mathrm{kg} \mathrm{ME},-0.10 \%$ available $\mathrm{P}$ and $-2.00 \%$ Digestible AA; NC2 = $P C-112.6 \mathrm{kcal} / \mathrm{kg} \mathrm{ME},-0.15 \%$ available $P$ and $-3.00 \%$ Digestible AA.

$A, B$ Means followed by different superscripts in the same column are different by the SNK test $(p<0.05)$.

x.y Means followed by different superscripts in the same column are different by the $F$ test $(p<0.05)$.

*not significant.

In the second trial, there was no significant interaction between nutritional levels and enzyme complex ( $p>0.05$ ) on metabolizable energy values (Table 4). AME values were higher than AMEn. According to Leeson \& Summers (2001), estimated energy values need to be corrected for nitrogen balance because it is not possible to ensure that all birds will have the same growth rate in a metabolism assay. When determined in growing broilers, AME values are commonly higher than AMEn values because there is high retention of nitrogen for protein deposition, particularly when endogenous and metabolic losses are considered (Nery et al., 2007).

As expected, the diets with reduced nutritional levels negatively influenced apparent metabolizable energy (AME) and apparent metabolizable energy corrected for nitrogen balance (AMEn) values $(p<0.05)$, whereas the PC diet promoted the highest AME and AMEn values. These results suggest that PC diet efficiently met the metabolizable energy requirements of the broilers. 
The dietary inclusion of the enzyme complex significantly increased $(p<0.05)$ AME and AMEn values on dry matter basis by $68.59 \mathrm{kcal} / \mathrm{kg}(2.06 \%)$ and $65.96 \mathrm{kcal} / \mathrm{kg}(2.03 \%)$, respectively. This suggests that the EC partially increased the availability of dietary non-starch polysaccharides, particularly those present in soybeans, which is rich in oligosaccharides. Several studies reported the capacity of enzymes to improve the nutrient digestibility of corn- and soybean mealbased diets (Brito et al., 2006; Rutherfurd et al., 2007; West et al., 2007; Viana et al., 2009), reducing the influence of antinutritional factors found in these feedstuffs.

Pugh and Charlton (1995) included a multienzyme complex, consisting of cellulose, protease, and xylanase $(1.0 \mathrm{~kg} / \mathrm{ton})$, in broiler diets based on soybean meal and they obtained an increasing by $7.2 \%$ in metabolizable energy values. Brito (2003), when supplementing a multi-enzyme complex to broiler diets containing different extruded soybeans, found higher AME (2.69\%) and AMEn (2.80\%) values compared with non-supplemented diets.

Aiming at reducing layer feed costs, Ny et al. (1998) tested two diets: one containing $2872.0 \mathrm{kcal} /$ $\mathrm{kg}$ and $17.5 \%$ of Crude Protein (CP) level, and the other with $3.5 \%$ energy reduction and the same CP level. The reduced-energy diet contained wheat middlings and was supplemented with an enzyme. Layer performance was not influenced by the diets, but a cost reduction of $5.2 \%$ was obtained with the reduced-energy diet.

This improvement in energy utilization was also found by other authors. Garcia et al. (2000) fed oneto 42-d-old broilers with diets based on soybean meal and extruded soybeans supplemented with $\alpha$-galactosidade, pectinases, celullase. The authors obtained an improvement by $9 \%$ in metabolizable energy utilization. This benefit was also observed by Dänicke et al. (2000), Hew et al. (1998), and Charlton (1996). Iwahashi (2009), working with growing quails. They also concluded that the supplementation of an enzyme complex (xylanase and $\beta$-glucanase) to diets based on corn and soybean meal allowed the reduction of dietary energy up to $119.9 \mathrm{kcal}$ of $\mathrm{ME} / \mathrm{kg}$ of feed without any negative effects on performance. The differences among studies are possibly due to differences in the type and combination of enzymes applied, in feedstuffs, bird age, and dietary energy content. In fact, exogenous enzymes are commonly supplemented to increase dietary energy levels or to improve energy utilization.
The interaction between nutritional levels and enzyme complex significantly $(p<0.05)$ affected phosphorus ( $P$ ) intake ( $g /$ bird), as shown in Table 5. Dietary nutritional levels significantly influenced $(p<0.05)$ phosphorus intake, which decreased when nutritional level was reduced. Within nutritional level, the inclusion of the enzyme complex increased phosphorus intake in 3.6\% in broilers fed the PC diet, but not when birds were fed the negative control diets.

Table 5 - Phosphorus (P) intake ( $\mathrm{g} / \mathrm{bird}$ ) of broilers fed diets containing or not the enzyme complex.

\begin{tabular}{|c|c|c|}
\hline \multirow{2}{*}{ Item } & \multicolumn{2}{|c|}{ Enzyme complex } \\
\hline & 0 & $200 \mathrm{~g} / \mathrm{ton}$ \\
\hline \multicolumn{3}{|l|}{ Diet $^{1}$} \\
\hline Positive Control (PC) & $3.88^{\mathrm{Ab}}$ & $4.02^{\mathrm{Aa}}$ \\
\hline Negative Control 1 (NC1) & $3.20^{\mathrm{Ba}}$ & $3.14^{\mathrm{Ba}}$ \\
\hline Negative Control 2 (NC2) & $2.92^{\mathrm{ca}}$ & $2.96^{\mathrm{ca}}$ \\
\hline \multicolumn{3}{|l|}{$p$-value } \\
\hline Diets & \multicolumn{2}{|c|}{$<0.001$} \\
\hline Enzyme complex & \multicolumn{2}{|c|}{$n s^{*}$} \\
\hline Diets x Enzyme complex & \multicolumn{2}{|c|}{0.015} \\
\hline CV (\%) & \multicolumn{2}{|c|}{2.84} \\
\hline
\end{tabular}

${ }^{1} \mathrm{NC} 1=\mathrm{PC}-75.05 \mathrm{kcal} / \mathrm{kg} \mathrm{ME},-0.10 \%$ available $\mathrm{P}$ and $-2.00 \%$ Digestible AA; NC2 = $P C-112.6 \mathrm{kcal} / \mathrm{kg} \mathrm{ME},-0.15 \%$ available $P$ and $-3.00 \%$ Digestible AA.

$A, B, C$ Means followed by different capital letters in the same column are different by the SNK test $(p<0.05)$.

a,bMeans followed by different small letters in the same row are different by the $\mathrm{F}$ test $(p<0.05)$.

*not significant.

There was no interaction between nutritional levels and enzyme complex ( $p>0.05)$ for $P$ excretion ( $\mathrm{g} / \mathrm{bird}$ ) and $\mathrm{P}$ retention ( $\mathrm{g} / \mathrm{bird}$ ) as shown in Table 6. Phosphorus excretion was reduced $(p<0.05)$ by $6.82 \%$ when the EC was included in the diet, demonstrating that the phytase present in the complex increased the availability of phosphorus present as phytate, increasing its utilization and reducing its excretion. Conversely, P retention increased by $10.3 \%$ with EC dietary addition. Higher $P$ retention allows reducing inorganic $P$ dietary inclusion levels as well as its excretion, contributing to reduce environmental pollution. Phosphorus retention was $4.4 \%$ higher $(p<0.05)$ in the broilers fed the EC, again demonstrating the effect of phytase. Preliminary studies have shown that exogenous phytase may improve phosphorus digestibility, reducing $P$ excretion and increasing $P$ retention in the body (Lelis et al., 2007; Graña, 2008) by breaking down the orthophosphate bound to the phytate molecule. 
Table 6 - Phosphorus (P) balance of broilers fed diets supplemented or not with the enzyme complex.

\begin{tabular}{lcc}
\hline Item & $\begin{array}{c}\text { P excretion } \\
(\mathrm{g} / \mathrm{b} \text { ird })\end{array}$ & $\begin{array}{c}\text { P retention } \\
(\mathrm{g} / \mathrm{bird})\end{array}$ \\
\hline Diet $^{1}$ & & \\
Positive Control (PC) & $2.05^{\mathrm{C}}$ & $1.88^{\mathrm{A}}$ \\
Negative Control 1 (NC1) & $1.60^{\mathrm{B}}$ & $1.56^{\mathrm{B}}$ \\
Negative Control 2 (NC2) & $1.46^{\mathrm{A}}$ & $1.48^{\mathrm{C}}$ \\
Enzyme complex & & \\
0 & $1.76^{\mathrm{x}}$ & $1.56^{\mathrm{y}}$ \\
200 g/t & $1.64^{\mathrm{y}}$ & $1.72^{\mathrm{x}}$ \\
$\mathrm{CV}(\%)$ & 5.23 & 7.91 \\
p-Value & & \\
Diets & $<0.001$ & $<0.001$ \\
Enzyme complex & $<0.001$ & $<0.001$ \\
Diets x Enzyme complex & $\mathrm{ns}$ & $\mathrm{ns}$ \\
\hline
\end{tabular}

${ }^{1} \mathrm{NC1}=\mathrm{PC}-75.05 \mathrm{kcal} / \mathrm{kg} \mathrm{ME},-0.10 \%$ available $\mathrm{P}$ and $-2.00 \%$ Digestible AA; NC2 = PC $-112.6 \mathrm{kcal} / \mathrm{kg} \mathrm{ME},-0.15 \%$ available $P$ and $-3.00 \%$ Digestible AA.

$A, B, C$ Means followed by different superscripts in the same row are different by the SNK test $(p<0.05)$.

x.yMeans followed by different superscripts in the same row are different by the $F$ test $(p<0.05)$.

*not significant.

The $\mathrm{N}$ excretion (g/bird), intake ( $\mathrm{g} / \mathrm{bird})$, and retention (g/bird) results are shown on Tables 7 and 8 . There was a significant interaction $(p<0.05)$ between nutritional levels and $\mathrm{EC}$ for $\mathrm{N}$ intake and $\mathrm{N}$ retention (both in $\mathrm{g} / \mathrm{bird}$ and as a \%).

Table 7 - Nitrogen $(\mathrm{N})$ excretion of broilers fed diets supplemented or not with the enzyme complex.

\begin{tabular}{lc}
\hline Item & $\begin{array}{c}\text { N excretion } \\
\text { (g/bird) }\end{array}$ \\
\hline Diet $^{1}$ & \\
Positive Control (PC) & 6.86 \\
Negative Control 1 (NC1) & 6.80 \\
Negative Control 2 (NC2) & 6.90 \\
Enzyme complex & \\
0 & $6.97^{x}$ \\
200 g/t & $6.74^{y}$ \\
CV (\%) & 3.72 \\
p-Value & \\
Diets & $n s^{*}$ \\
Enzyme complex & 0.003 \\
Diets x Enzyme complex & $n$ ns \\
\hline
\end{tabular}

${ }^{1} \mathrm{NC1}=\mathrm{PC}-75.05 \mathrm{kcal} / \mathrm{kg} \mathrm{ME},-0.10 \%$ available $\mathrm{P}$ and $-2.00 \%$ Digestible AA; NC2 = PC $-112.6 \mathrm{kcal} / \mathrm{kg} \mathrm{ME},-0.15 \%$ available $P$ and $-3.00 \%$ Digestible AA.

x.y Means followed by different superscripts in the same column are different by the $F$ test $(p<0.05)$.

*not significant.
Table 8 - Nitrogen balance of broilers fed diets supplemented or not with the enzyme complex.

\begin{tabular}{|c|c|c|c|c|}
\hline \multirow{3}{*}{ Item } & \multicolumn{2}{|c|}{ N Intake (g/bird) } & \multicolumn{2}{|c|}{ N Retention (g/bird) } \\
\hline & \multicolumn{2}{|c|}{ Enzyme complex } & \multicolumn{2}{|c|}{ Enzyme complex } \\
\hline & 0 & $200 \mathrm{~g} / \mathrm{ton}$ & 0 & $200 \mathrm{~g} / \mathrm{ton}$ \\
\hline \multicolumn{5}{|l|}{ Diet $^{1}$} \\
\hline Positive Control (PC) & $19.35^{\text {Aa }}$ & $18.48^{\mathrm{Bb}}$ & $12.33^{\mathrm{Aa}}$ & $11.77^{\mathrm{Bb}}$ \\
\hline Negative Control 1 (NC1) & $17.60^{\mathrm{cb}}$ & $18.63^{\mathrm{Ba}}$ & $10.65^{\mathrm{cb}}$ & $11.99^{\mathrm{Ba}}$ \\
\hline Negative Control 2 (NC2) & $18.52^{\mathrm{Bb}}$ & $19.51^{\mathrm{Aa}}$ & $11.59^{\mathrm{Bb}}$ & $12.64^{\mathrm{Aa}}$ \\
\hline \multicolumn{5}{|l|}{$p$-value } \\
\hline Diets & \multicolumn{2}{|c|}{$<0.001$} & \multicolumn{2}{|c|}{$<0.001$} \\
\hline Enzyme complex & \multicolumn{2}{|c|}{0.002} & \multicolumn{2}{|c|}{$<0.001$} \\
\hline Diets x Enzyme complex & \multicolumn{2}{|c|}{$<0.001$} & \multicolumn{2}{|c|}{$<0.001$} \\
\hline CV (\%) & \multicolumn{2}{|c|}{2.20} & \multicolumn{2}{|c|}{3.19} \\
\hline
\end{tabular}

${ }^{1} \mathrm{NC} 1=\mathrm{PC}-75.05 \mathrm{kcal} / \mathrm{kg} \mathrm{ME},-0.10 \%$ available $\mathrm{P}$ and $-2.00 \%$ Digestible AA; NC2 = $P C-112.6 \mathrm{kcal} / \mathrm{kg} \mathrm{ME},-0.15 \%$ available $P$ and $-3.00 \%$ Digestible AA.

$A, B, C$ Means followed by different capital letters in the same column are different by the SNK test $(p<0.05)$.

a.bMeans followed by different small letters in the same row are different by the $F$ test $(p<0.05)$.

Dietary nutritional level did not influence $(p>0.05)$ $N$ excretion, but it was affected $(p<0.05)$ by the addition of the $\mathrm{EC}$ in the diets. The supplementation of $\mathrm{EC}$ reduced $\mathrm{N}$ excretion by $3.3 \%$. The effect of the interaction between dietary nutritional level and EC inclusion was observed only on $\mathrm{N}$ intake and $\mathrm{N}$ retention. When the EC was not added in the diets, the $P C$ diet presented the highest nitrogen intake and the NC1 diet, the lowest $(p<0.05)$. However, when the EC was supplied, the birds fed the NC2 diet showed higher $(p<0.05) \mathrm{N}$ intake than those fed the PC and NC1 diets, which were not different. Similar results were found for $\mathrm{N}$ retention $(p<0.05)$. As expected, the NC1 and NC2 diets effectively reduced N intake and $\mathrm{N}$ retention, when compared with the PC diet, demonstrating the beneficial effects of the protease present in the EC added to the diets. Previous studies reported that phytate may complex with the protein molecule as well as with amino acids (AA) and small peptides in the gastrointestinal tract (Selle et al., 2000). In addition, it significantly increases AA flow through the small intestine, resulting in higher endogenous AA excretion in broilers (Cowieson et al., 2004).

The results of the present study suggest that the EC supplementation may relieve the adverse effects caused by the protein-phytate complex, reducing the waste of dietary nutrients, such as phosphorus, protein, and carbohydrates that compose the energy fraction of broiler diets. 
Pessôa GBS, Ribeiro Junior V, Albino LFT, Araújo WAG, Silva DL, Hannas M, Rostagno HS

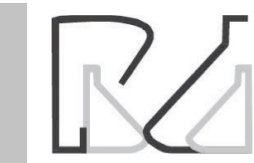

Therefore, the addition of the enzyme complex to broiler diets resulted in many benefits. It improved broiler performance, with the strongest impact on weight gain $(3.92 \%$ higher) and feed conversion ratio (2.74\% better) between 1 and 42 days of age. AME and AMEn utilization improved by $2.05 \%$ and $2.02 \%$, respectively. On average, phosphorus excretion was reduced by $6.82 \%$ and $P$ retention increased by $10.26 \%$, while nitrogen excretion was reduced by $3.30 \%$ and $\mathrm{N}$ retention increased by $5.30 \%$.

\section{CONCLUSION}

Based on the results of the present study, we recommend the addition of $200 \mathrm{~g}$ of the evaluated enzyme complex per ton of broiler feed, considering the nutrient reduction obtained when $100 \%$ of the nutritional matrix of the enzyme complex was considered in the formulation of feeds.

\section{ACKNOWLEDGMENTS}

The authors express their gratitude to all those who helped to perform the experiments, to Alltech Agroindustrial Ltda. for supplying the enzyme complex, incentive and financial support, and to CNPq and CAPES for the scholarships granted to the authors.

\section{REFERENCES}

Avila E, Arce J, Soto C, Rosas F, Ceccantini M, Mclntyre DR. Evaluation of an enzyme complex containing nonstarch polysaccharide enzymes and phytase on the performance of broilers fed a sorghum and soybean meal diet. Journal of Applied Poultry Research 2012;21:279-286.

Boguhn J, Rodehutscord M. Effects of nonstarch polysaccharide-hydrolyzing enzymes on performance and amino acid digestibility in turkeys. Poultry Science 2010;89:505-513.

Brito CO, Albino, LFT, Rostagno HS, Gomes PC, Carvalho DCO, Corassa A. Adição de complexo multienzimático em dietas à base de soja extrusada e desempenho de pintos de corte. Revista Brasileira de Zootecnia 2006;35(2):457-461.

Brito CO. Adição de complexo multienzimático em dietas com diferentes sojas extrusadas para pintos de corte [dissertation]. Viçosa (MG): Universidade Federal de Viçosa; 2003.

Campasino A, Williams M, Latham R, Bailey CA, Brown B, Lee JT. Effects of increasing dried distillers' grains with solubles and non-starch polysaccharide degrading enzyme inclusion on growth performance and energy digestibility in broilers. Journal of Applied Poultry Research 2015;24:135-144.

Campestrini E, Silva VTM, Appelt MD. Utilização de enzimas na alimentação animal. Revista Eletrônica Nutritime 2005:2(6):254-267.

Charlton P. Expanding enzyme application: Higher amino acid and energy values for vegetable proteins. Proceedings of the 12th Biotechnology in the Feed Industry; 1996; Nicholasville, Kentucky. USA: Alltech Technical Publications; 1996. p.317-326.
Enzyme Complex Added to Broiler Diets: Effects on Performance, Metabolizable Energy Content, and Nitrogen and Phosphorus Balance

Costa FGP, Goulart CC, Figueiredo DF, Oliveira CFS, Silva JHV. Economic and Environmental Impact of Using Exogenous Enzymes on Poultry Feeding. International Journal of Poultry Science 2008;7(4):311-314.

Costa FGP. Efeito da adição de enzimas nas rações de frango de corte [dissertation]. Areia (PB): Universidade Federal da Paraíba; 1996.

Cowieson AJ, Acamovic T, Bedford MR. The effects of phytase and phytic acid on the loss of endogenous amino acids and minerals from broiler chickens. British Poultry Science 2004;45:101-108.

Cowieson AJ. Strategic selection of exogenous enzymes for corn/soy-based poultry diets. Poultry Science 2010;47:1-7.

Dänicke S, Jeroch H, Böttcher W, Simon O. Interactions between dietary fat type and enzyme supplementation in broiler diets with high pentosan contents: effects on precaecal and total tract digestibility of fatty acids, metabolizability of gross energy, digesta viscosity and weights of small intestine. Animal Feed Science and Technology 2000;84(3):279-294

Dersjant-Li Y, van de Belt K, van der Klis JD, Kettunen H, Rinttila T, Awati A. Effect of multi-enzymes in combination with a direct-fed microbial on performance and welfare parameters in broilers under commercial production settings. Journal of Applied Poultry Research 2015;24:80 90.

Farran MT, Barbour, GW, Usayran NN, Darwish AH, Machlab HH, Hruby M, et al. Performance and carcass quality of broiler chickens fed a cornsoybean meal diet containing graded barley levels without or with enzyme. Journal of Poultry Science 2010;47:34-40

Figueiredo AN, Zanella I, Sakomura NK. Efeito da adição de enzimas em dietas à base de milho e tipos de soja sobre o desempenho de frangos de corte. Anais da Conferência Apinco de Ciências e Tecnologias Avícolas; 1998; Campinas, São Paulo. Brasil.

Francesch M, Geraert PA. Enzyme complex containing carbohydrases and phytase improves growth performance and bone mineralization of broilers fed reduced nutrient corn-soybean-based diets. Poultry Science 2009;88:1915-1924

García M, Lázaro R, Latorre MA, Gracia MI, Mateos GG. Influence of enzyme supplementation and heat processing of barley on digestive traits and productive performance of broilers. Poultry Science 2008;87:940-948.

Garcia, ERDM, Mukarani AE, Branco AF. Efeito da suplementação enzimática em rações com farelo de soja e soja integral extrusada sobre a digestibilidade de nutrientes, o fluxo de nutrientes na digesta ileal e desempenho de frangos. Revista Brasileira de Zootecnia 2000;29:14141426 .

Graña AL. Estudo de estratégias nutricionais para frangos de corte [thesis] Viçosa (MG): Universidade Federal de Viçosa; 2008.

Hahn-Didde D, Purdum SE. The effects of an enzyme complex in moderate and low nutrient-dense diets with dried distillers grains with solubles in laying hens. Journal of Applied Poultry Research 2014;23:23-33.

Hew LI, Ravindran V, Mollah Y, Bryden WL. Influence of exogenous xylanase supplementation on apparent metabolizable energy and amino acid digestibility in wheat for broiler chickens. Animal Feed Science and Technology 1998;75(2):83-92.

Ishibashi T, Yonemochi C. Possibility of amino acid nutrition in broiler. Journal of Animal Science 2002:73:155-165.

Iwahashi AS, Furlan AC, Scherer C, Ton APS, Lorençon L, Scapinello C. Utilização de complexo enzimático em rações para codornas de corte. Acta Scientiarum. Animal Sciences 2011;33(3):273-279.

Iwahashi AS. Utilização de complexo enzimático em dietas para codornas de corte [dissertation]. Maringá (PR): Universidade Estadual de Maringá; 2009. 
Pessôa GBS, Ribeiro Junior V, Albino LFT, Araújo WAG, Silva DL, Hannas M, Rostagno HS
Leeson S, Summers JD. Scott's nutrition of the chicken. 4th ed. Guelph: University Books; 2001.

Lelis GR, Albino LFT, da Silva CR, Rostagno HS, Gomes PC, Borsatto CG. Suplementação dietética de fitase sobre o metabolismo de nutrientes de frangos de corte. Revista Brasileira de Zootecnia 2010;39(8):17681773.

Nery, LR, Albino, LFT, Rostagno, HS, Campos, AMA, Silva, CR. Valores de energia metabolizável de alimentos determinados com frangos de corte. Revista Brasileira de Zootecnia 2007;36(5):1354-1358.

Ny LeP, Wyatt C, Creswell D. El uso de enzimas para maximizar la utilización de los nutrientes en dietas para ponedoras. In: Enzimas - Desarollando su potencial en dietas para aves basadas en milho/soja. Anais del Finfeeds International; 1998; Atlanta. EUA. p.32-37.

Penz Júnior AM, Enzimas em rações de aves e suínos. Anais da $35^{a}$ Reunião Anual da Sociedade Brasileira de Zootecnia; 1998; Botucatu, São Paulo. Brasil. p.165-178.

Perazzo Costa FG, Lima MR, Ceccantini ML, Neto RM, Goulart CC, Oliveira CFS, Vieira DVG, Santos CS. Exogenous enzyme complexes and linoleic acid to laying hens. Journal of Applied Poultry Research 2015;24:3036 .

Pugh R, Charlton P. Enzyme applications for plant proteins: time to look beyond cereals. In: Biotechnology in the Feed Industry - Proceedings of Alltech's 11th Annual Symposium; 1995; Loughborough, Leics. UK. p. 393-396.

Rostagno HS, Albino LFT, Donzele JL, Gomes PC, Oliveira RF, Lopes DC, et al. Brazilian tables for poultry and swine. 2nd ed. Viçosa: Editora UFV; 2005
Enzyme Complex Added to Broiler Diets: Effects on

Performance, Metabolizable Energy Content, and

Nitrogen and Phosphorus Balance

Rutherfurd SM, Chung TK, Moughan PJ. The effect of a commercia enzyme preparation on apparent metabolizable energy, the true ileal amino acid digestibility and endogenous ileal lysine losses in broiler chickens. Poultry Science 2007;86:665-672.

Sakomura NK, Rostagno HS. Métodos de pesquisa em nutrição de monogástricos. $3^{\mathrm{a}}$ ed. Jaboticabal: Editora Funep; 2007.

Selle PH, Ravindran V, Caldwell RA, Bryde, WL. Phytate and phytase: consequences for protein utilization. Nutrition Research Reviews 2000;13:255-278

Silva DJ, Queiroz AC. Análises de alimentos: métodos químicos e biológicos. $3^{\mathrm{a}}$ ed. Viçosa: Editora UFV; 2006

Tiwari SP, Gendley MK, Pathak AK, Gupta R. Influence of an enzyme cocktail and phytase individually or in combination in Ven Cobb broiler chickens. British Poultry Science 2010;51(1):92-100.

UFV - Universidade Federal de Viçosa. SAEG - Sistema de Análises Estatísticas e Genéticas. Viçosa; 2000.

Viana MTS, Albino LFT, Rostagno HS, Silva EA, Messias RKG, Pereira JPL. Efeito do uso de enzimas sobre o desempenho e metabolismo de poedeiras. Revista Brasileira de Zootecnia 2009;38(6):1068-1073.

West ML, Corzo A, Dozier III WA, Blair ME, Kidd MT. Assessment of dietary rovabio excel ${ }^{\circledR}$ in practical United States broiler diets. Journal of Applied Poultry Research 2007;16:313-321.

Yang ZB, Yang WR, Jiang SZ, Zhang GG, Zhang QQ, Siow KC. Effects of a thermotolerant multi-enzyme product on nutrient and energy utilization of broilers fed mash or crumbled corn-soybean meal diets. Journal of Applied Poultry Research 2010;19:38-45. 